\title{
Perubahan Fungsi Teba di Pekarangan Desa Nyuh Kuning
}

\author{
Cokorda Istri Arina Cipta Utari ${ }^{1}$ \\ 1. Prodi Studi Arsitektur, Fakultas Teknik, Universitas Udayana, Jl. PB Sudirman \\ Denpasar 80232, Indonesia \\ *E-mail: cokarinacipta@gmail.com
}

\begin{abstract}
Teba land change of function at Nyuh Kuning Village. Nyuh Kuning Village is one of four pakraman (traditional) village in Mas Village, Ubud District, Gianyar Regency, Bali Province which has developed well because of its tourism sector. The rapid development of tourism has resulted significant changes in the use of land in this village. This study aims to explore the pattern of teba landuses changes due to tourism, the factors that cause these changes, and the consequences of these changes on green open space. The research method used was qualitative research. The sample selection used was purposive random sampling technique which was processed by systematic triangulation. The result showed that the change of teba was as follows: $22,7 \%$ for domestic dwelling, $6,8 \%$ for comercial buildings/domestic buildings with half of the land functioned for plantation for religious purposes and for food needs, 15,9\% without teba land, 9,1\% are still intact, and the rest of $45,5 \%$ as a commercial building for financial needs of the community. The factors that affect the change in the function of teba were internal factors; social, economic and cultural. As well as external factors such as political and policy factors. Futhermore, the consequences of changes in the function of the teba have a significant impact on the disruption of the bio-ecological (physical) functions, social and cultural functions, the balance of the ecosystem, and the aesthetic/architectural functions of the traditional Balinese heritage.
\end{abstract}

Keywords: green open space, influencing factors, teba land change of function

\section{Pendahuluan}

Desa Nyuh Kuning dikenal sebagai salah satu desa adat/desa pakraman dari empat desa yang ada di Desa Mas, Kecamatan Ubud, Kabupaten Gianyar, Provinsi Bali. Berdasarkan data kependudukan dari monografi desa tahun 2019, Desa Nyuh Kuning berpenduduk 980 jiwa dengan 260 kepala keluarga. Lokasi Desa Nyuh Kuning termasuk jalur wisata yang cukup padat dari Denpasar menuju Ubud, atau menuju Goa Gajah dan Tampak Siring. Kemudian, di tahun 2002, terjadi Bom Bali I yang berpengaruh terhadap perekonomian dan pariwisata Bali secara menyeluruh termasuk di Desa Nyuh Kuning. Menurut kamus Bahasa Bali "Teba" berasal dari kata teben yang berarti bagian bawah atau belakang. Jadi pengertian teba adalah ruang terbuka pada bagian belakang dari pekarangan rumah tradisional Bali yang bersemak. Untuk menstabilkan perekonomian masyarakat, sekitar tahun 2005, pengurus/perangkat Desa Nyuh Kuning mulai mencoba mengembangkan Desa Nyuh Kuning sebagai desa wisata dan salah satunya dengan memanfaatkan area teba sebagai penunjang akomodasi pariwisata untuk mendukung perekonomian di desa tersebut. Oleh masyarakat Bali secara turun-temurun biasanya teba dimanfaatkan sebagai lahan untuk berkebun dalam mengolah berbagai tanaman obat-obatan tradisional, tanaman pangan dan tanaman untuk kebutuhan upacara keagamaan. Bagi beberapa masyarakat teba merupakan area yang sangat ideal untuk berternak ayam, babi ataupun sapi. Perubahan semakin terasa cepat akibat adanya pembangunan Hotel Ubud Wana Resort di tahun 2015 berkapasitas 73 kamar dan memberi konsekuensi yang luar biasa bagi perkembangan masyarakat di Desa Nyuh Kuning. Hal tersebut menyebabkan masyarakat berlomba-lomba melakukan pembangunan untuk mengakomodasi kegiatan wisatawan yang begitu banyak berkunjung di Desa Nyuh Kuning. Selanjutnya I Gusti Agung Adi Wiraguna (2019) mengungkapkan bahwa konsekuensi yang terjadi jika pembangunan terlalu berlebihan dan tidak terkontrol maka peralihan fungsi teba akan menyebabkan berkurangnya ruang terbuka hijau (RTH) yang ada di pekarangan dan berpengaruh pada lingkungan, yaitu menurunnya ketersediaan air tanah, komposisi massa bangunan yang padat dapat 
mengakibatkan kepenatan pada pemukiman. Bahwasanya leluhur orang Bali telah menciptakan sebuah sistem ekologi pada tata ruang arsitektur Bali sebagai bentuk hubungan yang baik antara manusia dengan alam (Raharjo \& Munandar, 1998).

Oleh sebab itu, maka perlu dilakukan penelitian dengan tujuan untuk mengidentifikasi perubahan yang terjadi pada area teba, faktor-faktor yang mempengaruhi, serta konsekuensi perubahan fungsi teba di pekarangan Desa Nyuh Kuning.

\section{Metode}

Penelitian ini dilakukan di sepanjang koridor Nyuh Bulan dan Nyuh Gading, yang merupakan koridor utama di Desa Nyuh Kuning yang terletak di Desa Dinas Mas, Kecamatan Ubud, Kabupaten Gianyar dan berbatasan langsung dengan beberapa desa yang terkenal dengan pariwisata alam dan budayanya. Seperti Desa Peliatan, Kelurahan Ubud, Desa Pakraman Lodtunduh, dan Desa Pakraman Pengosekan.

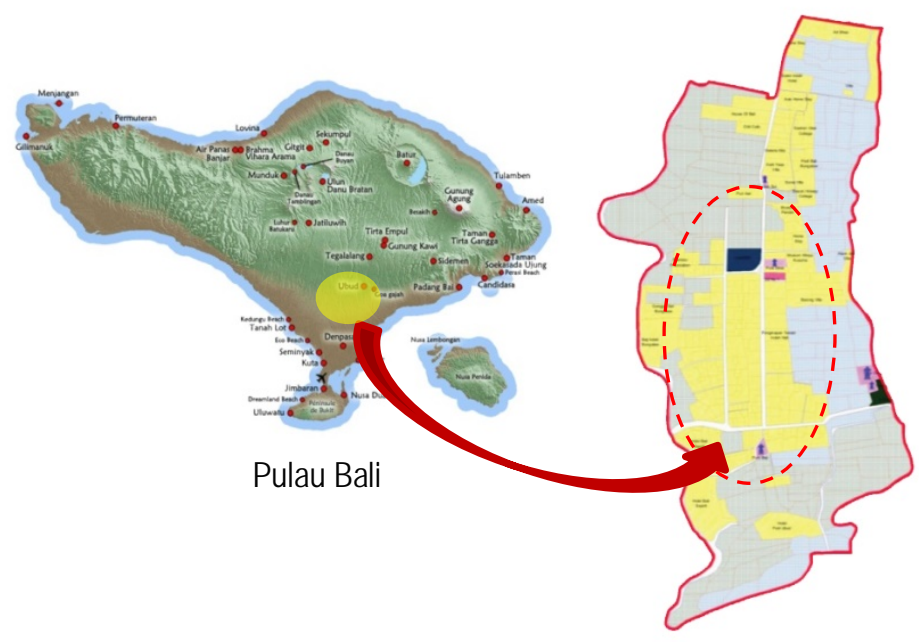

Gambar 1. Lokasi Penelitian di Koridor Desa Nyuh Kuning

Penelitian ini dilakukan selama satu setengah tahun, yaitu dimulai dari bulan Mei 2019 sampai Oktober 2020 dengan mengambil 44 obyek pekarangan yang ada di sepanjang koridor Desa Nyuh Kuning dan dikelompokan menjadi 5 jenis studi kasus yaitu 1) Teba sebagai rumah tinggal, 2) Teba sebagai area komersial, 3) Teba masi utuh, 4) tidak ada Teba, 5) Teba multifungsi. Metode yang digunakan dalam penelitian ini yaitu kualitatif dengan pendekatan studi kasus. Strategi penelitian ini adalah dengan menggabungkan data yang ditemukan dari satu teknik pengumpulan data satu dengan teknik pengambilan data lainnya. Jenis data yang digunakan dalam penelitian ini adalah data kualitatif yang diperoleh dari sumber data yaitu sumber data primer dengan penentuan informan dalam penelitian ini ditetapkan berdasarkan teknik purposive random sampling melalui teknik pengumpulan data yaitu wawancara mendalam, observasi, dan literature review. Kemudian, data diolah secara triangulasi yaitu dengan cara mengecek kebenaran data atau informasi yang diperoleh peneliti dari sudut pandang yang berbeda dengan cara mengurangi sebanyak mungkin bias yang terjadi pada saat pengumpulan dan analisis data, sumber yang kajiannya dirangkum sebagai suatu simpulan penelitian, menata secara sistematis catatan hasil observasi, wawancara, penggambaran, sketsa, dan lainnya untuk meningkatkan pemahaman peneliti tentang kasus yang diteliti dan menyajikan temuan bagi orang lain, dari hasil kegiatan yang dilakukan, baik berdasarkan studi pustaka, studi lapangan, data yang terkumpul dikategorisasikan, ditata urutan penelaahannya. Data yang diperoleh kemudian dianalisis disajikan dalam bentuk teks atau penjelasan naratif maupun bentuk tabel serta gambar 


\section{Hasil dan Pembahasan}

\subsection{Gambaran umum pariwisata di Desa Nyuh Kuning}

Berdasarkan data dinas pariwisata Kabupaten Gianyar, industri pariwisata dalam sepuluh tahun terakhir (2010-2020) rata-rata mengalami peningkatan terkait jumlah kunjungan wisatawan domestik maupun mancanegara. Sedangkan pada tahun 2020 mengalami penurunan yang tajam akibat pandemi covid-19. Seperti yang terlihat pada tabel dan gambar dibawah.

Tabel 1. Kunjungan Wisatawan Domestik dan Mancanegara ke Kabupaten Gianyar

\begin{tabular}{rcc}
\hline \multicolumn{1}{c}{ No. } & Tahun & Jumlah Wisatawan \\
\hline 1. & 2010 & 70.458 \\
2. & 2011 & 68.749 \\
3. & 2012 & 109.168 \\
4. & 2013 & 245.228 \\
5. & 2014 & 289.448 \\
6. & 2015 & 322.604 \\
7. & 2016 & 504.928 \\
8. & 2017 & 652.382 \\
9. & 2018 & 586.933 \\
10. & 2019 & 758.595 \\
11. & 2020 & 50.165 (hingga bulan maret) \\
\hline
\end{tabular}

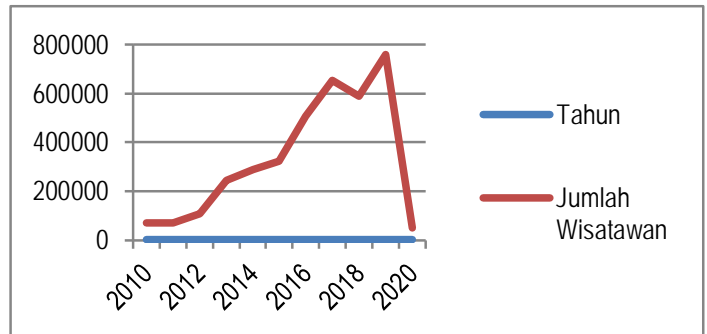

Gambar 2. Grafik Kunjungan Wisatawan Domestik dan Mancanegara ke Kabupaten Gianyar

Berdasarkan data monografi desa, jumlah penduduk Desa Nyuh Kuning pada Maret 2020 yaitu sebanyak 909 orang tercatat secara administratif, dengan total sebanyak 209 KK dari 2.840 KK di Desa Mas Ubud-Gianyar. Pengembangan pariwisata di Desa Nyuh Kuning tidak terlepas dari pemanfaatan lahan teba sebagai penunjang akomodasi pariwisata. Dengan menjaga, mengelola dan melestarikan lahan teba, berarti usaha-usaha untuk mempertahankan kawasan ruang terbuka hijau (RTH) secara alami telah dimiliki oleh masyarakat Bali. Teba sebagian besar telah mengalami perubahan menjadi berbagai jenis bangunan yang beragam, beralih fungsi, dan bahkan menjadi sumber penggerak perekonomian di Desa Nyuh Kuning. Permasalahan yang mendasar dalam pelestarian lahan teba sebagai ruang terbuka hijau (RTH) yaitu adanya peluang untuk pergerakan perekonomian di Desa Nyuh Kuning yang sangat strategis dan potensial menjadi akomodasi pariwisata bagi wisatawan domestik maupun mancanegara.

Sebaran fungsi teba di Desa Nyuh Kuning

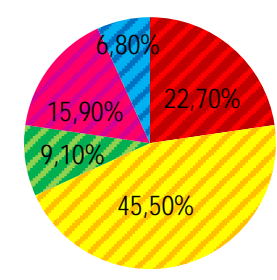

$$
\begin{aligned}
& \text { Teba sebagai rumah } \\
& \text { tinggal } \\
& \text { Teba sebagai area } \\
& \text { komersial } \\
& \text { Teba masih Utuh } \\
& \text { Tidak ada teba } \\
& \text { Teba multi fungsi }
\end{aligned}
$$

Gambar 3. Persentase Perubahan Fungsi Teba di Desa Nyuh Kuning (Survei Lapangan, 2020) 
Pada gambar 3 tersebut, menunjukkan bahwa sebagian besar teba berubah menjadi bangunan komersial yaitu sebanyak 20 pekarangan (45,5\%) Perubahan ini bertujuan untuk meningkatkan nilai komersil lahan teba yang berpotensi menjadi berbagai bangunan guna menambah penghasilan. Hal ini selaras dengan yang diungkapkan oleh Riana dkk (2014) yang menyebutkan bahwa peralihan fungsi sebuah lahan yang tadinya tidak produktif dilihat sebagai peluang oleh masyarakat setempat untuk meningkatkan perekonomian keluarga. Berikut adalah gambar dari perubahan fungsi teba di pekarangan Desa Nyuh Kuning (Gambar 4 dan Gambar 5):

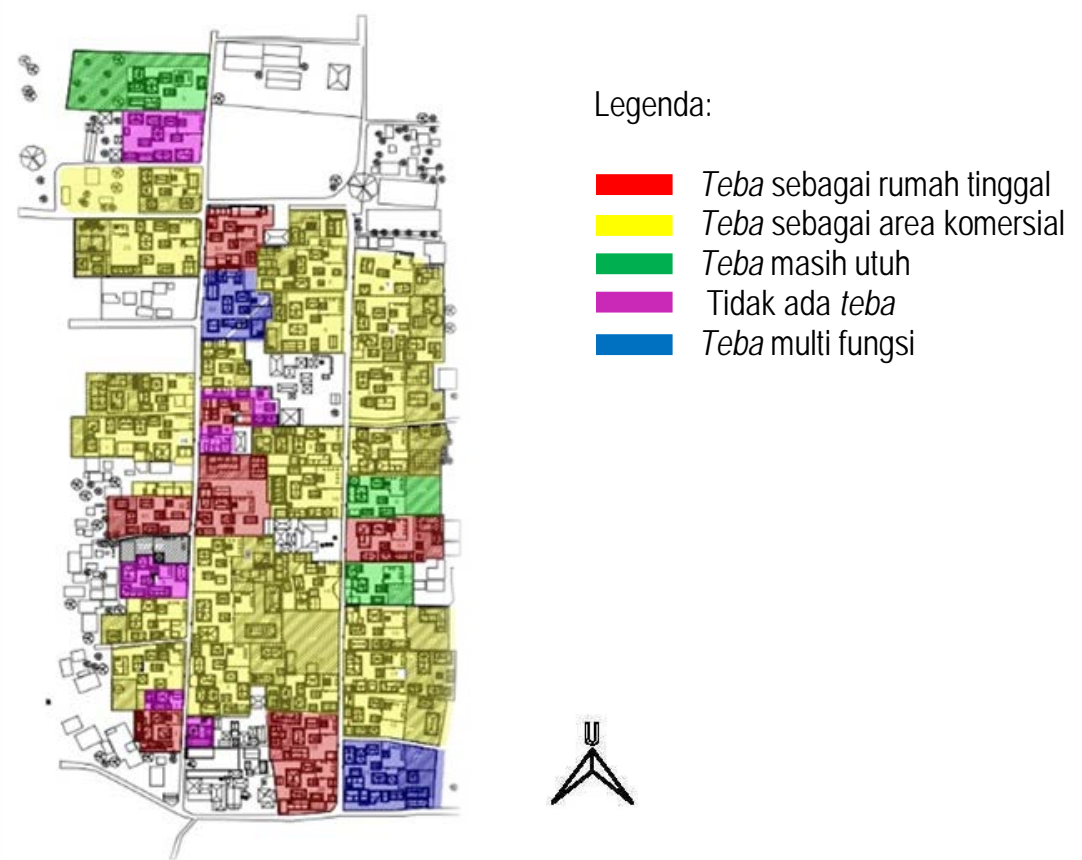

Gambar 4. Peta Pemanfaatan Fungsi Lahan Teba Di Koridor Desa Nyuh Kuning

(Survei Lapangan, 2020)

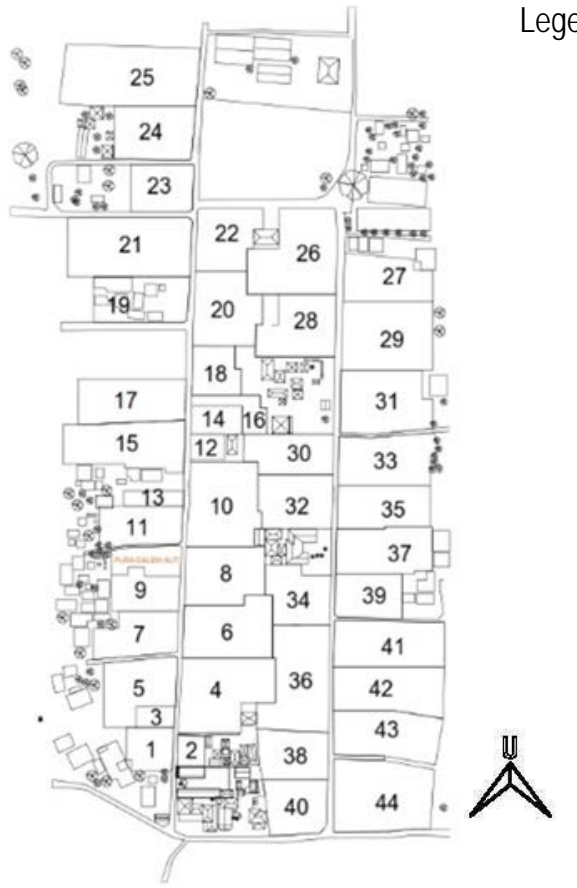

Legenda:
1. Made Sumantra
21. Made Kirim
2. Wayan Kapuk
22. Ketut Muka
3. Made Sumarta
23. Nyoman Marsa
4. Nyoman Suwena
5. Pak Ruja
6. Pak Mawi
7. Pande Jiwa
8. Nyoman Sugama
9. Nyoman Wenda
10. Prof. Windia
11. Wayan Warsa
12. Nyoman Wirawan
13. Made Sura
14. Wayan Pamit
15. Ketut Runa
16. Kadek Sugiantara
17. Nyoman Wenda
18. Ketut Kecor
19. Ketut Sarpa
20. Mangku Narka
24. Ketut Sudarsana
25. Nyoman Kaler
26. Made Subaga
27. Nyoman Madra
28. Made Sandiasa
29. Wayan Wartawa
30. Pak Kiying
31. Ketut Tulus
32. Made Sweca
33. Ketut Bandiastra
34. Wayan Sujendra
35. Nyoman Tomik
36. Ketut Wiguna
37. Ketut Sapra
38. Wayan Ajin
39. Wayan Brata
40. Wayan Sama
41. Made Yasa
42. Made Suja
43. Ketut Murja
44. Made Lipit

Gambar 5. Peta Kepemilikan Lahan Pekarangan di Koridor Desa Nyuh Kuning (Survei Lapangan, 2020) 


\section{a) Kasus I. Teba masih utuh}

Hasil survei dan dokumentasi yang dilakukan di Desa Nyuh Kuning mendapatkan hasil bahwa terdapat 4 pekarangan dengan fungsi teba yang belum mengalami perubahan secara fungsi dan fisik yaitu sebanyak 9,1\% dari keseluruhan sampel yang diteliti

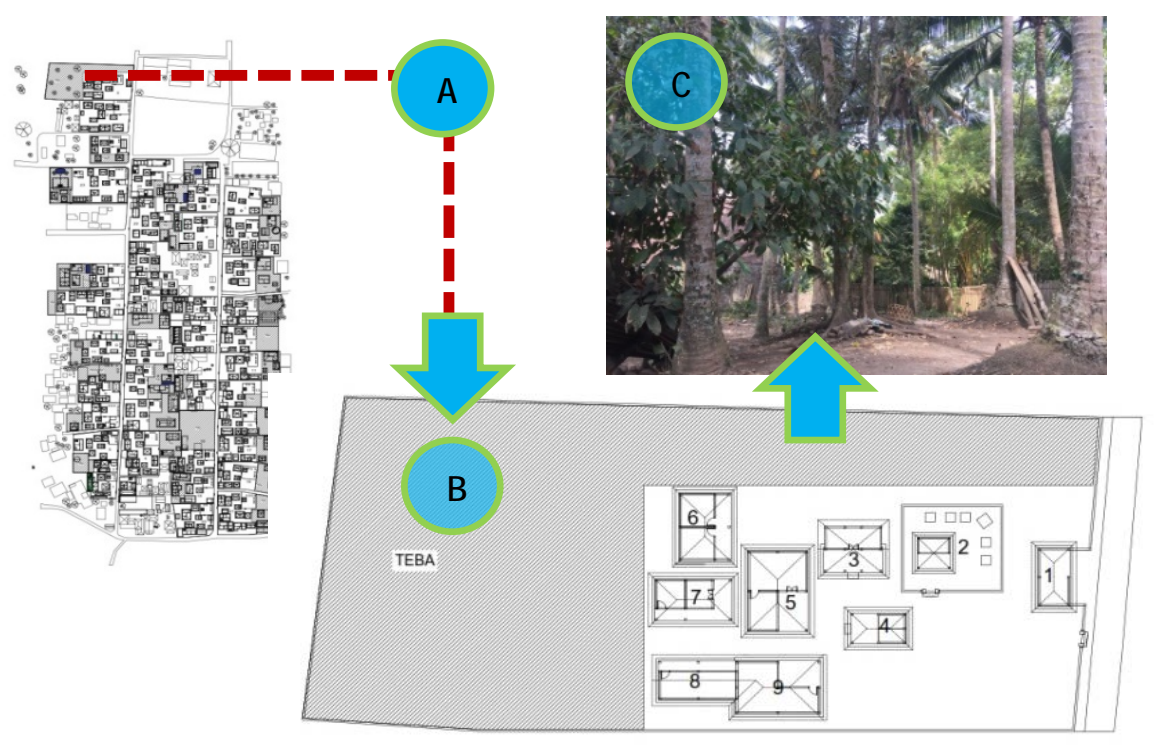

Keterangan:

1. Coffee Shop

2. Tempat Suci

3. Bale Daja

4. Bale Dangin

5. Bale Daja

6. Kamar

7. Kamar

8. Dapur

9. Bale Delod

Gambar 6. Pekarangan Nyoman Kaler di Koridor Nyuh Bulan

(Survei Lapangan, 2020)

Gambar 6. menunjukkan bahwa Nyoman Kaler masih tetap mempertahankan lahan teba di pekarangan rumahnya. Nyoman Kaler dengan nomor rumah 25 yang berlokasi di koridor Nyuh Bulan dan memiliki 3 KK ini memilih untuk mempertahankan lahan teba miliknya untuk keperluan menanam berbagai jenis tanaman yang diperlukan untuk sarana upacara keagamaan seperti pohon kelapa.

\section{b) Kasus II. Teba sebagai area komersial.}

Pada kasus berikutnya, terdapat 20 pekarangan dengan fungsi teba yang berubah menjadi bangunan komersial yaitu sebanyak $45,5 \%$ untuk meningkatkan nilai komersil lahan teba menjadi berbagai bangunan guna menambah penghasilan.

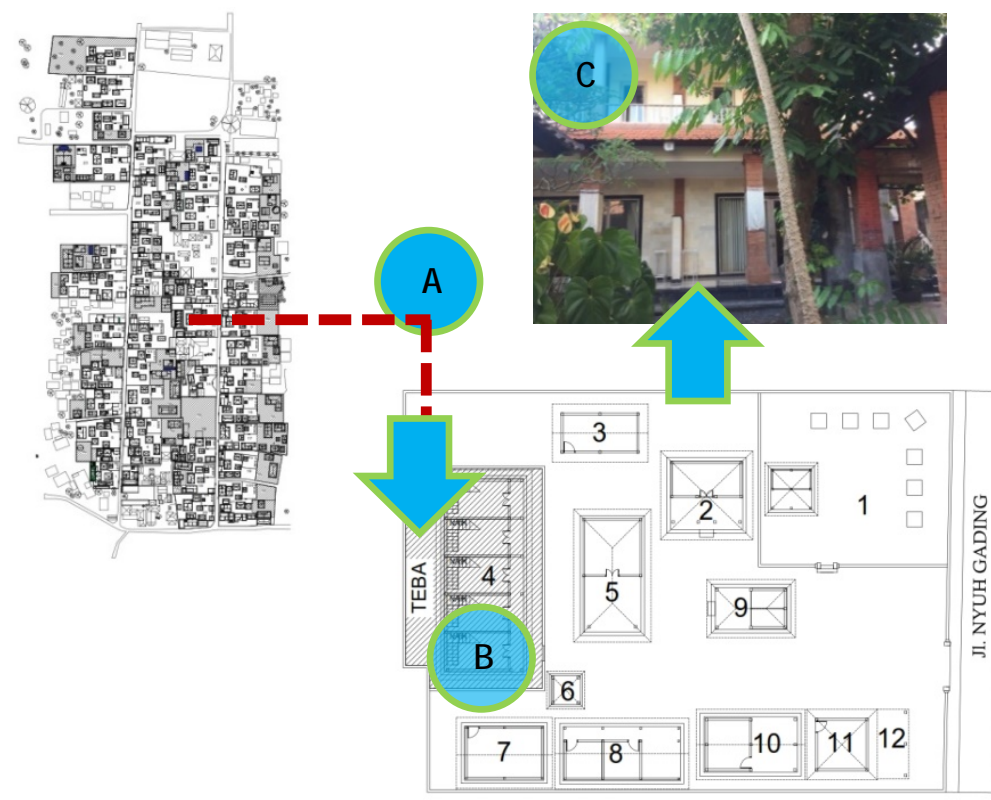

Keterangan:

1. Tempat suci

2. Bale daja

3. Bale

4. Teba sebagai homestay

5. Bale dauh

6. Bale

7. Paon

8. Bale delod

9. Bale dangin

10. Bale delod

11. Kamar

12. Garasi

Gambar 7. Pekarangan Made Sweca Teba Menjadi Homestay di Koridor Nyuh Gading.

(Survei Lapangan, 2020) 
c) Kasus III. Teba sebagai rumah tinggal.

Data selanjutnya menunjukkan bahwa sebanyak 22,7 \% fungsi teba yang dilaih fungsikan untuk kebutuhan rumah tinggal pribadi karena adanya penambahan anggota keluarga, Seperti pada gambar 8. Wayan Ajin merupakan salah satu penduduk Desa Nyuh Kuning yang bertempat di koridor Nyuh Gading, memilih untuk mengalih fungsikan lahan teba sebagai rumah tinggal pribadi.

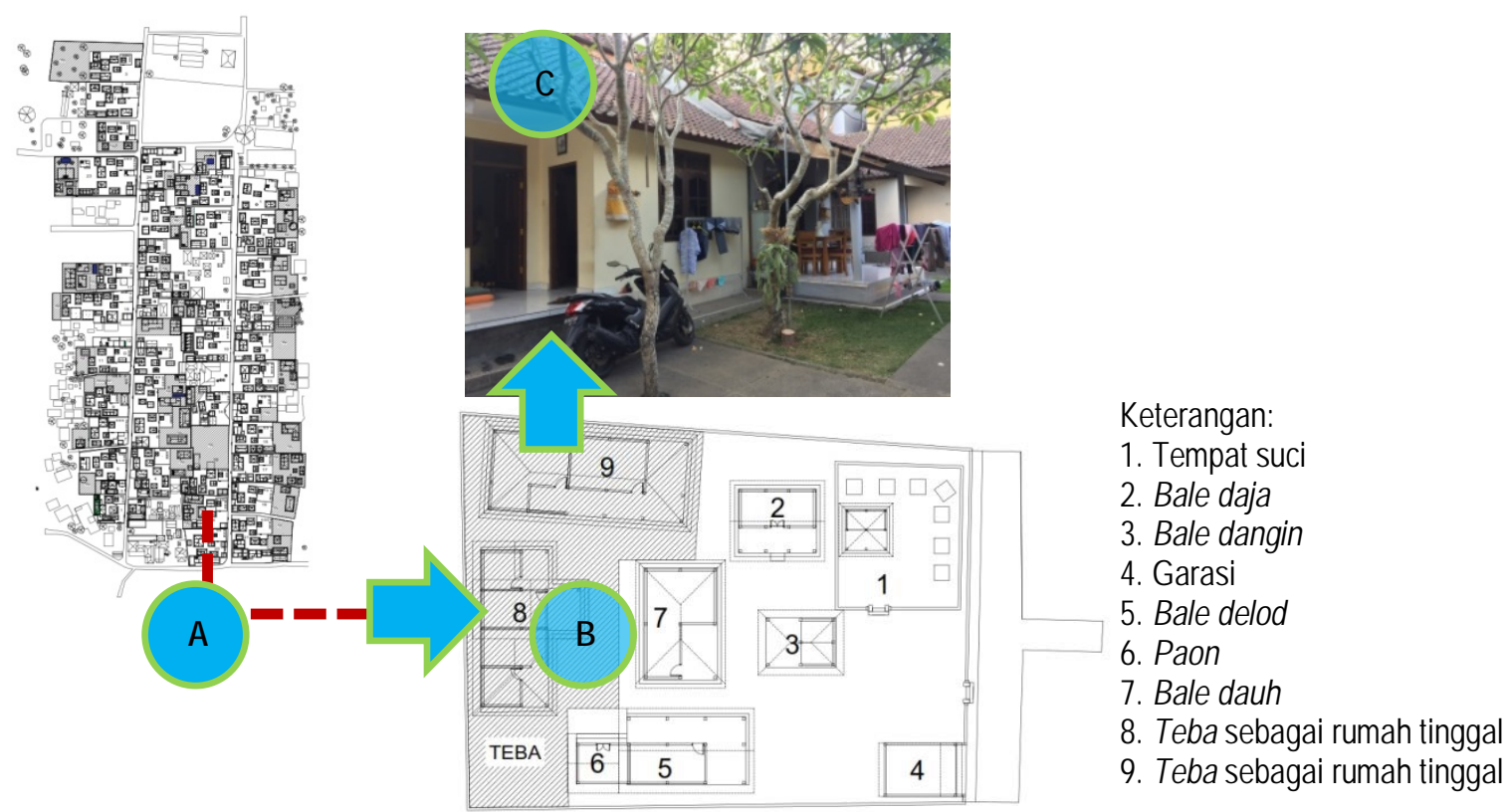

Gambar 8. Pekarangan Wayan Ajin Teba Menjadi Rumah Tinggal di Koridor Nyuh Gading.

(Survei Lapangan, 2020)

\section{d) Kasus IV. Teba multi fungsi}

Kemudian, untuk kasus keempat, sebanyak $6,8 \%$ teba dimanfaatkan sebagai multi fungsi, seperti Mangku Narka mengalihfungsikan lahan teba separuhnya untuk homestay dan sisanya dimanfaatkan untuk bercocok tanam maupun menanam bunga mitir (bunga untuk sarana upacara yadnya/persembahyangan).

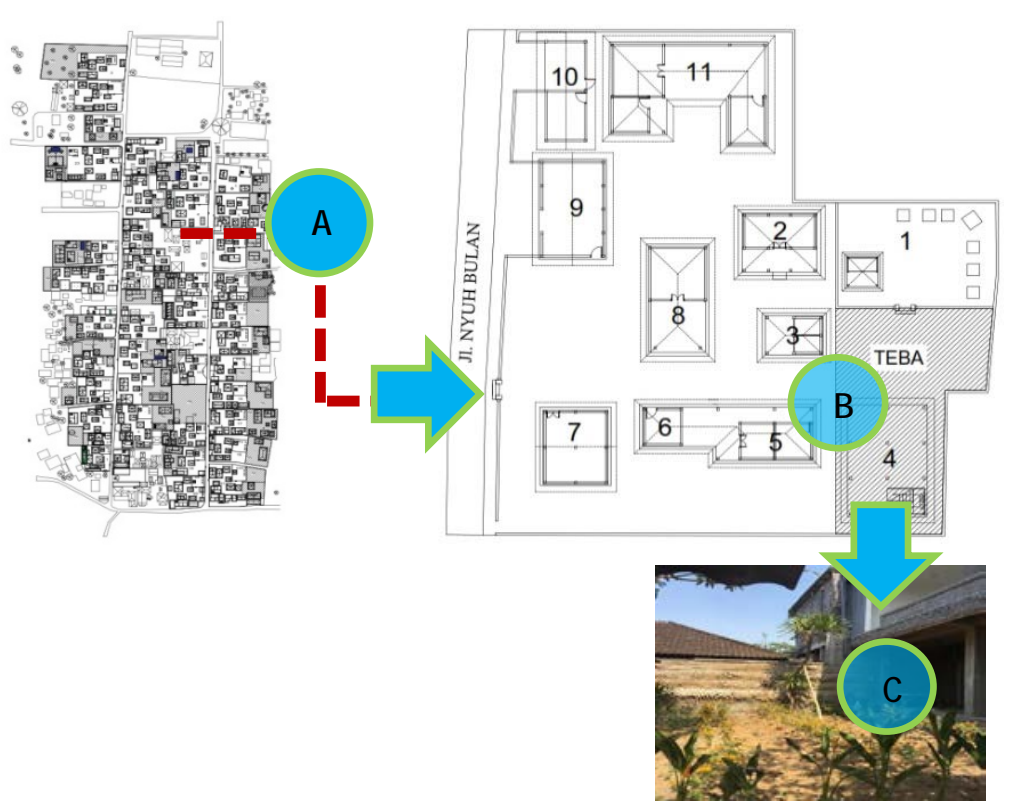

Keterangan:

1. Tempat suci

2. Bale daja

3. Bale dangin

4. Teba multifungsi

5. Bale delod

6. Paon

7. Kamar tidur

8. Bale dauh

9. Warung

10. Garasi

11. Kamar

Gambar 9. Pekarangan Mangku Narka Teba Multifungsi (Homestay \& Bercocok Tanam) di Koridor Nyuh Bulan. (Survei Lapangan, 2020) 


\section{e) Kasus V. Tidak ada teba.}

Dari hasil studi lapangan, 15,9\% tidak terdapat teba di pekarangan rumah tinggalnya. Seperti yang diungkapkan oleh Nyoman Wenda bahwa pekarangan rumah tinggalnya memang tidak memiliki teba karena minimnya luasan lahan pekarangan.

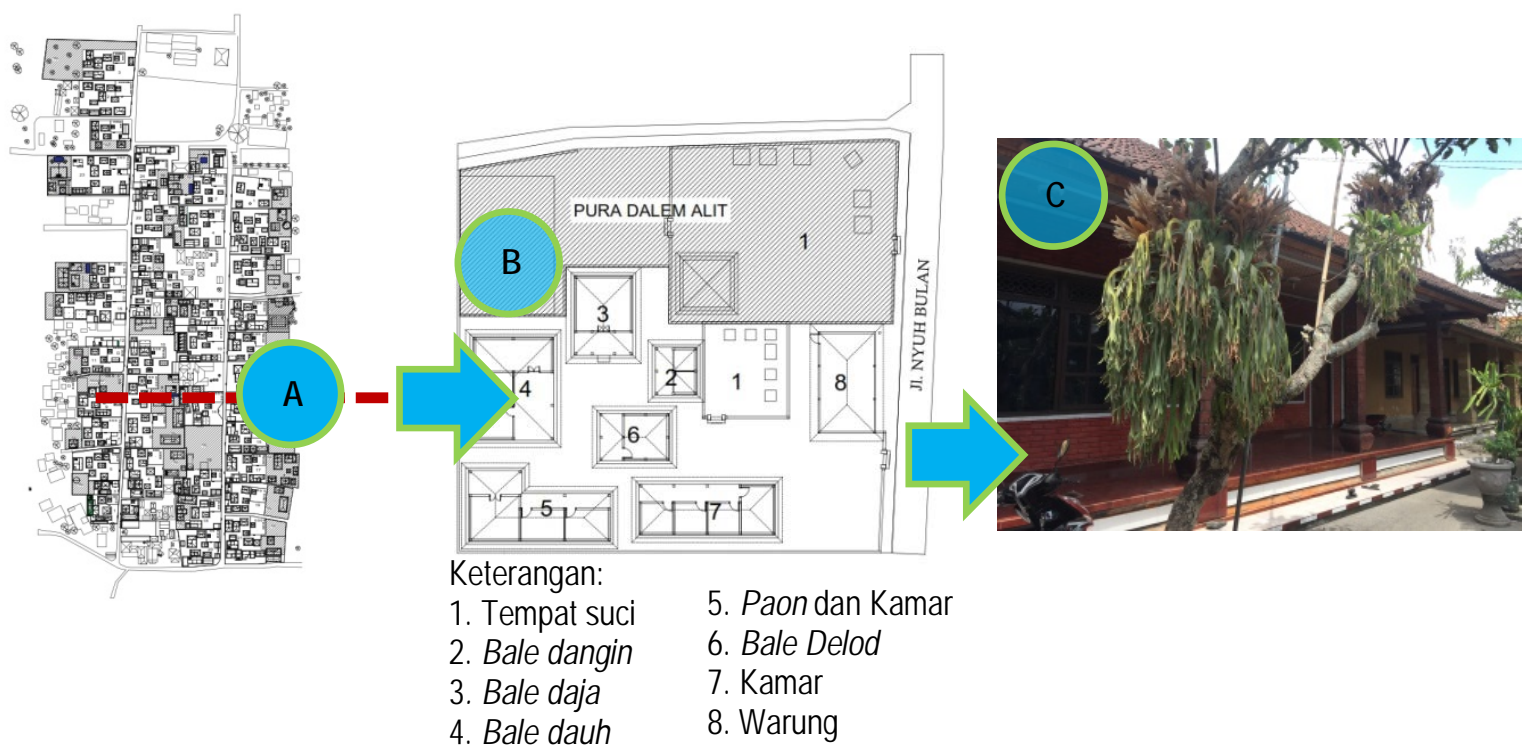

Gambar 10. Pekarangan Nyoman Wenda Tidak Ada Teba, di Koridor Nyuh Bulan.

(Survei Lapangan, 2020)

\subsection{Faktor-faktor yang mempengaruhi perubahan fungsi teba di Desa Nyuh Kuning}

Faktor sosial, karena pesatnya perkembangan pariwisata, sehingga beberapa masyarakat memilih mengalihfungsikan lahan teba dengan menjual lahan teba dan bekerjasama dengan investor untuk ikut mengembangkan kawasan wisata desa, yang nantinya hasil tersebut untuk biaya pendidikan anak sampai ke jenjang perguruan tinggi, untuk upacara ngaben, maupun renovasi rumah.-Faktor tersebut merupakan kebutuhan sosial masyarakat yang ada di Desa Nyuh Kuning. Sesuai dengan yang diungkapkan oleh Santoso (2011) bahwa perubahan merupakan sifat dasar dari masyarakat, ini mengubah metafor "kehidupan sosial" seperti kehidupan sosial itu sendiri.

Faktor ekonomi, masyarakat Desa Nyuh Kuning yang mengalami situasi yang cukup genting di tahun 2000-an saat terjadi bom Bali I dimana kerajinan patung yang dimiliki Desa Nyuh Kuning tidak lagi menjadi promadona wisatawan. Banyak masyarakat yang kehilangan mata pencahariannya dan hanya bisa menikmati hasil yang dulu mereka peroleh sehingga memilih untuk mengalihfungsikan lahan teba dikarenakan kebutuhan ekonomi yang semakin meningkat dan melihat peluang investor yang berkeinginan mengontrak wilayah teba yang sebelumnya dianggap belum berfungsi dengan baik dan penuh dengan semak-semak.

Berikut dapat dilihat pada gambar 11 mengenai gambaran umum dari perubahan fungsi teba di Desa Nyuh Kuning menjadi lahan komersil hingga pemanfaatan lahan untuk keperluan upacara yadnyal persembahyangan.
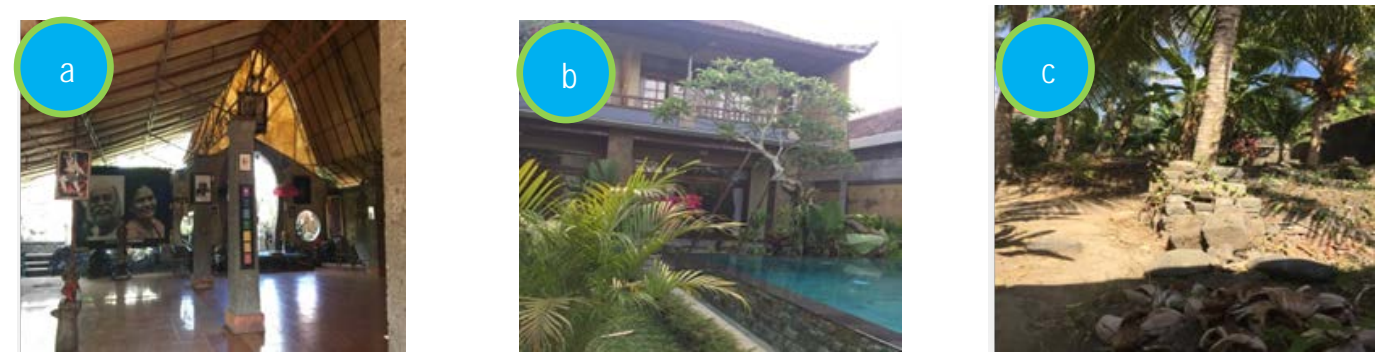

Gambar 11. Perubahan Umum Lahan Teba di Desa Nyuh Kuning (a. perubahan sebagian tempat yoga; b. perubahan sebagai villa, c. perubahan sebagai lahan perkebunan kelapa)

(Survei Lapangan, 2019) 
Faktor ketiga adalah faktor budaya, seiring berkembangnya jaman, sebagian besar masyarakat di Desa Nyuh Kuning melihat potensi wisata yang sangat besar dengan gaung dari visi dan misi Desa Nyuh Kuning untuk menjadi kawasan desa wisata. Sehingga hal ini mendorong masyarakat untuk menjadikan teba sebagai kawasan komersial. Kegiatan komersial ini tidak hanya dari segi pembangunan yang ada di Desa Nyuh Kuning, tetapi juga faktor dari Desa Nyuh Kuning yang memiliki daya tarik budaya dan tradisi yang unik dan menarik wisatawan untuk datang menetap untuk waktu yang cukup lama, sebagai tempat singgah maupun sebagai tempat untuk mengembangkan bisnis bagi wisatawan asing.

Selanjutnya faktor politis dan faktor kebijakan, perubahan lahan teba di Desa Nyuh Kuning tidak terlepas dari adanya tokoh-tokoh berpengaruh yang membuat perubahan di Desa Nyuh Kuning berkembang sangat pesat dan mendunia. Seperti keterangan dari Kelian Desa Nyuh Kuning I Wayan Eka Putra menyebutkan bahwa villa, homestay, café, dan usaha-usaha lainnya baik oleh investor maupun oleh masyarakat itu sendiri wajib untuk membayar pajak kepada pihak desa serta memberikan dana Corporate Social Responbility (CSR) untuk kepentingan pembangunan fasilitas umum di Desa Nyuh Kuning seperti yadnya, pembangunan/perbaikan pura, maupun pembangunan jalan. Pertama dan yang paling utama mempengaruhi adalah munculnya peran 'tokoh berpengaruh' dalam proses awal pengembangan pariwisata. yang tersimbolisasi pada figur Pemerintah. Kemunculan 'tokoh berpengaruh' dalam proses awal inisiasi pengembangan wisata di Desa Nyuh Kuning selain karena alasan formalitas politik kenegaraan (sebagai kepala daerah), juga terkandung alasan keterkaitan kultural pada tahun 2008-2012-an yang menjadi salah satu faktor kuat dalam pengembangan wisata di Desa Nyuh Kuning. Selaras dengan hasil penelitian Kusumastuti, dkk (2020) menyebutkan bahwa adaptasi, pencapaian tujuan, integrasi dan latensi mempengaruhi disrupsi suatu budaya dan perubahan di masyarakat. Dari pembahasan diatas, menunjukkan bahwa sektor kebijakan tidak dapat terlepas dari sektor politik yang di kendalikan oleh pemerintah.

\subsection{Konsekuensi perubahan fungsi teba di pekarangan Desa Nyuh Kuning.}

Dari hasil wawancara mendalam, seperti yang diungkapkan oleh Pande Ketut Jiwa, bahwa perubahan teba di Desa Nyuh Kuning berkembang sangat pesat, sehingga mengakibatkan perubahan fungsi bio-ekologi (fisik) seperti suhu udara yang semakin kering dan panas akibat berkurangnya kawasan teba sebagai ruang terbuka hijau (RTH). Ditambah lagi dengan kebiasaan turun-menurun masyarakat Bali yang dapat memprediksi musim panas/hujan, hal ini menjadi tidak menentu sepanjang tahun. Musim dan cuaca tidak lagi dapat di prediksi berdasarkan sasih (perhitungan perubahan musim di Bali).

Lebih lanjut lagi, keuntungan yang hilang akibat berkurangnya ruang terbuka hijau (RTH) yaitu pada siang hari, dengan adanya ruang terbuka hijau (RTH) maka secara alami udara panas akan terdorong ke atas dan sebaliknya pada malam hari udara dingin akan turun di bawah tajuk pepohonan, dengan demikian dapat dibayangkan jika lahan-lahan teba telah berubah menjadi bangunan, tentu manfaat tersebut tidak lagi masyarakat rasakan. Sehingga mempengaruhi perkembangan alami dari ekosistem alam serta berpengaruh secara langsung terhadap sosial-budaya masyarakat. Seperti keterangan dari Kelian Desa Nyuh Kuning; I Wayan Eka Putra menyebutkan saat ini telah lebih dari $>30 \%$ teba dimanfaatkan sebagai kawasan komersial yaitu sekitar 85-90\% lahan teba telah dialihfungsikan oleh masyarakat di Desa Nyuh Kuning.

I Gusti Agung Adi Wiraguna (2019) dalam penelitiannya mengungkapkan bahwa idealnya suatu kawasan, setidaknya masyarakat dapat mempertahankan sekitar 30\% ruang terbuka hijau (RTH) untuk menjaga keseimbangan alam. Tentu terdapat keraguan apakah di kawasan Desa Nyuh Kuning memiliki kawasan ruang terbuka hijau (RTH) yang memadai untuk turut ikut dalam menjaga keseimbangan ekosistem alam semesta sebagai daerah Eko-Wisata yang berkelanjutan. Menjadi sebuah pertanyaan besar apakah penghijauan lewat berbagai tumbuhan dan tanaman hias dapat menggantikan proporsi tanaman-tanaman rindang yang tumbuh subur sebelumnya di kawasan teba yang dimiliki oleh masyarakat. Hal tersebut berhubungan dengan pembentukan awig-awig desa adat berdasarkan tata cara kebiasaan masing-masing desa adat yang dibuat pemerintah dalam hal tata cara penyuratan dan pendaftaran awig-awig desa adat di Bali (Sastra dkk, 2020). Lebih lanjut, berdasarkan hasil observasi yang ada, dengan berubahnya teba menjadi bangunan-bangunan, memberikan konsekuensi pada perubahan kawasan ini yaitu terdapat "bangunan tidak teratur" dan "kawasan terpisah" akibat dari pembangunan wilayah baru oleh investor maupun pengembangan teba oleh pemilik menjadi kawasan komersial. Seperti yang diungkapkan oleh 
Sriwardani, dkk (2020) bahwa kawasan adat memberi batas antara "dalam" dan "luar". Pemisahan "dalam" dan "luar" ini memiliki perbedaan dalam menciptakan kesakralan ruang dan kondisi manusia yang ada di lingkungan tersebut. Sehingga tatanan arsitektur dan arsitektur lansekapnya tidak lagi sesuai dengan warisan leluhur atas kepemilikan atau eksistensi teba.

\section{Simpulan}

Adapun kesimpulan yang dapat peneliti tarik dari diskusi tersebut adalah perubahan-perubahan yang terjadi selama 10 tahun terakhir, kawasan teba telah berubah menjadi berbagai kawasan yaitu 22,7\% untuk rumah tinggal pribadi, teba sebagai multifungsi sebanyak 6,8\%, 15,9\% tidak ada teba, 9,1\% teba masih utuh dan yang tertinggi yaitu sebanyak $45,5 \%$ teba sebagai bangunan komersial untuk menambah penghasilan/kebutuhan finansial masyarakat. Dimana perubahan-perubahan yang terjadi dikelompokkan menjadi 5 kasus perubahan yaitu; 1) teba sebagai rumah tinggal, 2) teba sebagai area komersial, 3) teba masih utuh, 4) tidak ada Teba, 5) teba multifungsi.

Faktor-faktor yang mempengaruhi perubahan teba di Desa Nyuh Kuning, adalah faktor internal, faktor eksternal. Konsekuensi perubahan fungsi teba yaitu terganggunya fungsi bio-ekologis (fisik), terganggunya fungsi sosial, ekonomi dan budaya, terganggunya keseimbangan ekosistem alam, serta terganggunya fungsi estetis/arsitektur warisan tradisional bali. Masyarakat dapat diberikan wadah untuk edukasi tentang pentingnya peranan teba maupun ruang terbuka hijau privat (RTH privat), serta dapat disusun peraturan dengan kesepakatan bersama atau awig-awig/perarem bahwa lahan terbangun tidak boleh lebih dari $60 \%$ untuk mempertahankan teba (meminimalkan alih fungsi lahan teba) sehingga teba dapat tetap lestari. Dengan adanya penelitian ini dapat menjadi acuan ataupun landasan dalam pelaksanaan kegiatan studi lanjutan ke depannya terkait teba maupun ruang terbuka hijau privat (RTH privat).

\section{Daftar Pustaka}

Adi Wiraguna, I Gusti Agung (2019). Pengendalian Alih Fungsi Lahan Sawah Sebagai Upaya Pemenuhan Ruang Terbuka Hijau Kota (RTHK) Di Kota Denpasar: Tesis. Universitas Udayana

Dinas Pariwisata Kabupaten Gianyar. (2020). Data Kunjungan Wisatawan Asing di Kabupaten Gianyar, periode 2010-2020

Effendy, S. (2009). Konsekuensi Pengurangan Ruang Terbuka Hijau (RTH) Perkotaan Terhadap Peningkatan Suhu Udara Dengan Metode Penginderaan Jauh (Impact Reducing Urban Green Space Towards Increasing Air Temperature Using Landsat Data). Agromet. Bogor, Indonesia, 23(2), Pp. 169-181.Doi: 10.29244/J.Agromet.23.2.169-181.

Kusumastuti, E. I. \& Widjajantie K. (2020). Pola Interaksi Simbolik Dan Pewarisan Kesenian Jaran Kepang Semarangan Berbasis Agil Di Era Disrupsi. Mudra Jurnal Seni Budaya, 35(3):337-343.

Kurniasari, M., \& Ariastita, P. G. (2014). Faktor-faktor yang mempengaruhi alih fungsi lahan pertanian sebagai upaya prediksi perkembangan lahan pertanian di Kabupaten Lamongan. Jurnal Teknik ITS, 3(2), C119-C124.

Monografi Desa Mas, Kecamatan Ubud (2020). Laporan Data Penduduk Desa Nyuh Kuning Menurut Jumlah KK, periode Maret 2020.

Nanang, M. (2011). Sosiologi Perubahan Sosial. Jakarta: Rajawali Pers.

Rahardini, Dewi AA Sg. (2017). Pemanfaatan Lahan "Teba" Dalam Konservasi Sumber Daya Air. Paduraksa 3(2):17-21

Raharjo, S., \& Munandar, A. A. (1998). Sejarah Kebudayaan Bali: Kajian Perkembangan dan Konsekuensi Pariwisata. Direktorat Jenderal Kebudayaan.

Riana, I Nengah; Widiastuti; Primayatna, Ida Bagus Gde (2014). Kajian Alih Fungsi Ruang Terbuka Hijau Di Kota Denpasar. SPACE,1(1), April 2014.

Sastra Wibawal. P., Gelgell. P., \& Marthal. W. (2020). Tata Cara Penyuratan Dan Pendaftaran Awig-awig Desa Adat di Bali (Dari Desa Mawacara ke Bali Mawacara). Mudra Jurnal Seni Budaya, 35(3), 257265.

Sidarta, I Wayan Tagel (2002), Dampak Perkembangan Pariwisata Terhadap Kondisi Lingkungan, Sosial, dan Ekonomi Masyarakat ( Studi Kasus Kawasan Pariwisata Sanur, Denpasar-Bali). Tesis, Magister IImu Lingkungan Universitas Diponogoro.

Santoso, I. B., Musa, F. T., \& Latare, Z. (2015). Perubahan Sosial Ekonomi Masyarakat. Kim Fakultas IImu Sosial: Skripsi. Universitas Sriwijaya. 
Sriwardani N., Dienaputra R., Machdalena S., \& Kartika N. (2020). Ruang Adat di Kampung Dukuh Dalam sebagai Bentuk Kehidupan Spiritual. Mudra Jurnal Seni Budaya, 35(3), 344-351.

Sugiyono. (2006). Metode Penelitian Kuantitatif kualitatif dan R\&D. Bandung: Alfabeta.

Sukawati, Tjokorda Oka Artha Ardana. (2008). Perubahan Spasial Desa Adat Ubud, Gianyar, Bali, dalam Era Globalisasi : Sebuah Kajian Budaya (Disertasi). Denpasar: Universitas Udayana. 